Bull. Mater. Sci., Vol. 10, No. 5, August 1988, pp. 46i 465. (9) Printed in India.

\title{
Development of Thiobacillus ferrooxidans ATCC 19859 strains tolerant to copper and zinc
}

\author{
G P BRAHMAPRAKASH, PRESTON DEVASIA, K S JAGADISH, \\ $\mathrm{K}$ A NATARAJAN and ${ }^{*} \mathrm{G}$ RAMANANDA RAO \\ Department of Metallurgy, ${ }^{*}$ Microbiology and Cell Biology Laboratory, Indian Institute of \\ Science, Bangalore 560012 , India

\begin{abstract}
A study was carried out to develop strains of Thiohacillus ferrooxidans ATCC 19859 tolerant to higher levels of heavy metal ions. Strains of $T$. ferrooxidans capable of growing in $\mathrm{Cu}^{2+}(30 \mathrm{~g} / \mathrm{L})$ and $\mathrm{Zn}^{2+}(60 \mathrm{~g} / \mathrm{L})$ have been obtained. The ability of strains colerant to either copper or zinc to grow in medium containing both the metals has been examined. The copper-tolerant strain $(25 \mathrm{~g} / \mathrm{L})$ grows better in the medium containing both metals $\left(\mathrm{Cu}^{2+} 25 \mathrm{~g} / \mathrm{L}\right.$ and $\left.\mathrm{Zn}^{2+} 40 \mathrm{~g} / \mathrm{L}\right)$ compared to the zinc-tolerant strain $(40 \mathrm{~g} / \mathrm{L})$.
\end{abstract}

Keywords. Thiobacillus ferrooxidans; tolerance to copper; tolerance to zinc; iron oxidation.

\section{Introduction}

Thiobacillus ferrooxidans is the most widely studied micro-organism in biohydrometallurgical processes because of its ability to dissolve metals, mainly from sulphide minerals. Microbiological leaching of sulphide-bearing concentrates has also been reported (Torma et al 1972; Torma and Subramanian 1974; Sakaguchi et al 1976). During leaching of concentrates the level of the metal ions' in solution increases markedly. For an organism to play an effective role in leaching process, it has to be tolerant to high levels of metal ions. For optimum recovery of metals from mineral concentrates, strains tolerant to higher concentrations of heavy metal ions singly or in combination, need to be developed (Olson and Kelly 1986). The present study was undertaken to develop strains of $T$. ferrooxidans tolerant to higher levels of $\mathrm{Cu}^{2+}$ and $\mathrm{Zn}^{2+}$. The ability of these strains to grow in medium containing both $\mathrm{Cu}^{2+}$ and $\mathrm{Zn}^{2+}$ has also been investigated.

\section{Materials and methods}

T. ferruoxidans ATCC 19859 was obtained from Prof. H L Ehrlich, Rensselaer Polytechnic Institute, Troy, New York, USA.

The organism was maintained in $9 \mathrm{~K}$ medium at $\mathrm{pH} 2.3$ (Silverman and Lundgren 1959). Ferrous sulphate solution $\left(44.8 \mathrm{~g}\right.$ of $\mathrm{FeSO}_{4} \cdot 7 \mathrm{H}_{2} \mathrm{O}$ in $100 \mathrm{ml}$ of medium) was sterilized by passing through a Millipore membrane filter (pore size: $0.45 \mu \mathrm{m}$ ). To $80 \mathrm{ml}$ of medium in a $250 \mathrm{ml}$ Erlenmeyer flask, sterilized by autoclaving, $10 \mathrm{ml}$ of ferrous sulphate solution was added. This was then inoculated with $10 \mathrm{ml}$ of a $72 \mathrm{~h}$ old culture of $T$. ferrooxidans. The flask was kept on a rotary shaker $(240 \mathrm{rpm})$ at $30 \pm 2{ }^{\circ} \mathrm{C}$. The growth was monitored by quantitating the ferrous-iron oxidized at $24 \mathrm{~h}$ intervals.

The concentration of ferrous-iron in the culture was determined as follows: $2 \mathrm{ml}$ of $10 \mathrm{M} \mathrm{H}_{2} \mathrm{SO}_{4}$ was added to $1 \mathrm{ml}$ of the culture in $100 \mathrm{ml}$ conical flask and diluted with $25 \mathrm{ml}$ of distilled water. To this $0.1 \mathrm{ml}$ of $o$-phosphoric acid was added. The 
solution was titrated with $0.025 \mathrm{~N}$ potassium dichromate using $0.2 \mathrm{ml}$ of barium diphenyl amine sulphonate as the indicator. Under the conditions of assay $1 \mathrm{ml}$ of potassium dichromate solution used corresponds to $1.4 \mathrm{mg}$ of ferrous-iron.

Strains of $T$. ferrooxidans tolerant to high levels of metals were obtained by repeated culturing of the organism in $9 \mathrm{~K}$ medium supplemented with indicated levels of $\mathrm{Cu}^{2+}$ and $\mathrm{Zn}^{2+}$. The sulphate salts of the metals were used in the study and were of analar grade quality. Redox potential and $\mathrm{pH}$ were monitored with a platinum-saturated calomel electrode couple and combined electrode respectively.

Strains of $T$. ferrooxidans made tolerant to either $\mathrm{Cu}^{2+}(25 \mathrm{~g} / \mathrm{L})$ or $\mathrm{Zn}^{2+}(40 \mathrm{~g} / \mathrm{L})$ were used to examine their ability to grow in media containing both the metals at the levels indicated. For this $9 \mathrm{~K}$ medium supplemented with $\mathrm{Cu}^{2+}(25 \mathrm{~g} / \mathrm{L})$ and $\mathrm{Zn}^{2+}$ $(40 \mathrm{~g} / \mathrm{L})$ was inoculated with the culture $(10 \% \mathrm{v} / \mathrm{v})$ of the tolerant strains. The growth was monitored by following the extent of ferrous iron oxidized by the method described above.

\section{Results and discussion}

The growth pattern of $T$. ferrooxidans ATCC 19859 in $9 \mathrm{~K}$ medium containing different levels of $\mathrm{Cu}^{2+}$ is shown in figure 1A. The growth of the organism was slightly inhibited upto $48 \mathrm{~h}$ at $5 \mathrm{~g} / \mathrm{L}$ of $\mathrm{Cu}^{2+}$. However, this inhibition was not evident at later stages of growth $(96 \mathrm{~h})$. A marked inhibition was observed at $10 \mathrm{~g} / \mathrm{L}$ or more of $\mathrm{Cu}^{2+}$. However, on prolonged incubation (192 h) the organism showed recovery in growth at $10 \mathrm{~g} / \mathrm{L}$ of $\mathrm{Cu}^{2+}$ but not at $20 \mathrm{~g} / \mathrm{L}$ of $\mathrm{Cu}^{2+}$ (figure $1 \mathrm{~A}$ ). The growth profile of $T$. ferrooxidans tolerant to $10 \mathrm{~g} / \mathrm{L}$ of $\mathrm{Cu}^{2+}$ when subcultured into medium containing higher levels of $\mathrm{Cu}^{2+}$ is presented in figure $1 \mathrm{~B}$. It is evident that

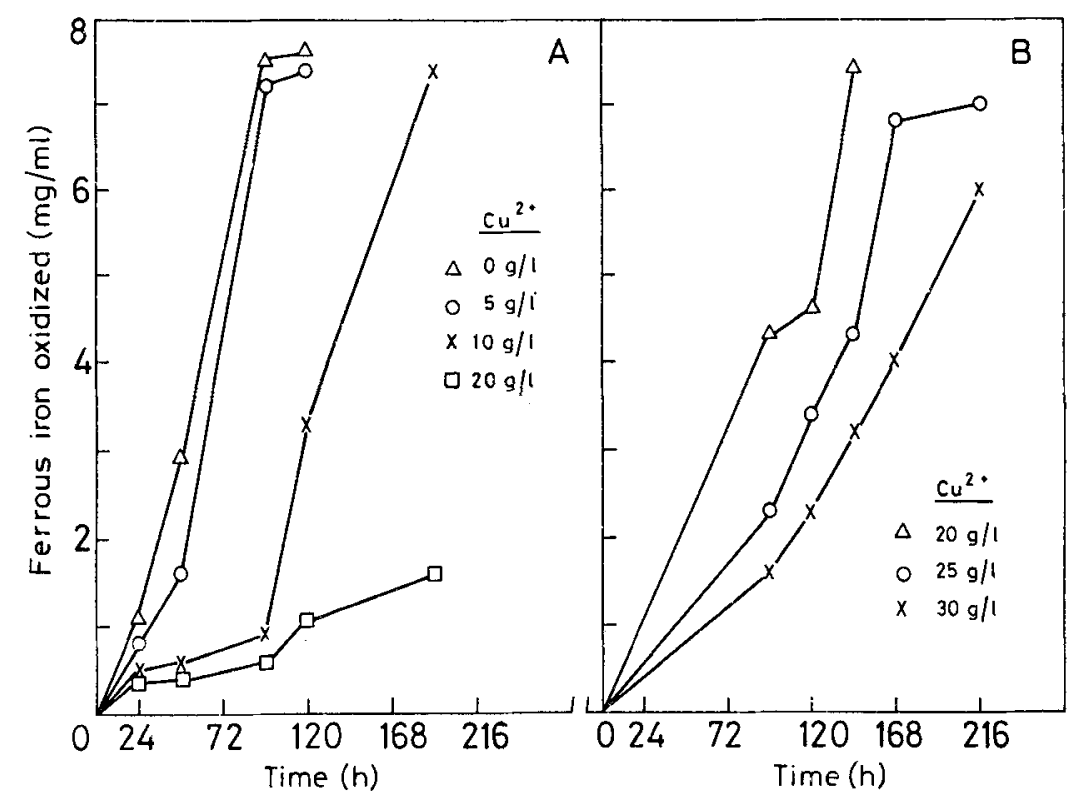

Figure 1. Development of tolerance of $T$. ferrooxidans to increasing levels of $\mathrm{Cu}^{2+}$. Tolerance of $(A)$ unadapted and (B) adapted $(10 \mathrm{~g} / \mathrm{L})$ strains to different concentrations of $\mathrm{Cu}^{2+}$. 
the strain tolerant to $10 \mathrm{~g} / \mathrm{L}$ of $\mathrm{Cu}^{2+}$ was able to grow at higher concentrations of $\mathrm{Cu}^{2+}(20 \mathrm{~g} / \mathrm{L}$ and above) while an unadapted culture was totally inhibited.

The redox potential values were found to increase rapidly when a tolerant strain was cultured in a medium containing metal ions. At the same time there was no significant changes in $\mathrm{pH}$ values during growth. Earlier reports have shown inhibitory concentrations of $\mathrm{Cu}^{2+}$ to be more than $1 \mathrm{~g} / \mathrm{L}$ (Tuovinen et al 1971) whereas T. ferrooxidans ATCC 19859 is inhibited only at $5 \mathrm{~g} / \mathrm{L}$ and above.

Figure $2 \mathrm{~A}$ represents the growth of $T$. ferrooxidans in medium containing different levels of $\mathrm{Zn}^{2+}$. The growth of the organism was inhibited by $\mathrm{Zn}^{2+}(20 \mathrm{~g} / \mathrm{L})$ only during initial stages $(48 \mathrm{~h})$. After $48 \mathrm{~h}$ the growth in the presence of $\mathrm{Zn}^{2+}$ was comparable with the control. The extent of inhibition observed during the initial $48 \mathrm{~h}$ was proportional to the concentration of $\mathrm{Zn}^{2+}$ in the medium. The ability of the strain made tolerant to $\mathrm{Zn}^{2+}(20 \mathrm{~g} / \mathrm{L})$ to grow at higher levels of $\mathrm{Zn}^{2+}$ is presented in figure $2 \mathrm{~B}$. The adapted/tolerant strain shows a better growth rate than the unadapted strain. However, at high concentrations of $\mathrm{Zn}^{2+}$ an inhibition was observed. The tolerance to $\mathrm{Zn}^{2+}$ could however be developed by repeated subculturing in the presence of the metal ion. Other reports have shown that $T$. ferrooxidans was inhibited by $\mathrm{Zn}^{2+}$ at more than $10 \mathrm{~g} / \mathrm{L}$ (Tuovinen et al 1971). In this study we have developed T. ferrooxidans ATCC 19859 strains tolerant to $\mathrm{Cu}^{2+}(25-30 \mathrm{~g} / \mathrm{L})$ and $\mathrm{Zn}^{2+}(60 \mathrm{~g} / \mathrm{L})$.

The strain tolerant to $\mathrm{Zn}^{2+}(40 \mathrm{~g} / \mathrm{L})$ when cultured in medium containing $\mathrm{Cu}^{2+}$ (row 1) shows poor growth upto 12 days (table 1). Under similar conditions $\mathrm{Cu}^{2+}$. tolerant strain (row 2) grows very well in the presence of $\mathrm{Zn}^{2+}(40 \mathrm{~g} / \mathrm{L})$ and reaches the maximal growth much earlier (12 days). It showed a consistently higher rate of growth compared to the $\mathrm{Zn}^{2+}$-tolerant one.

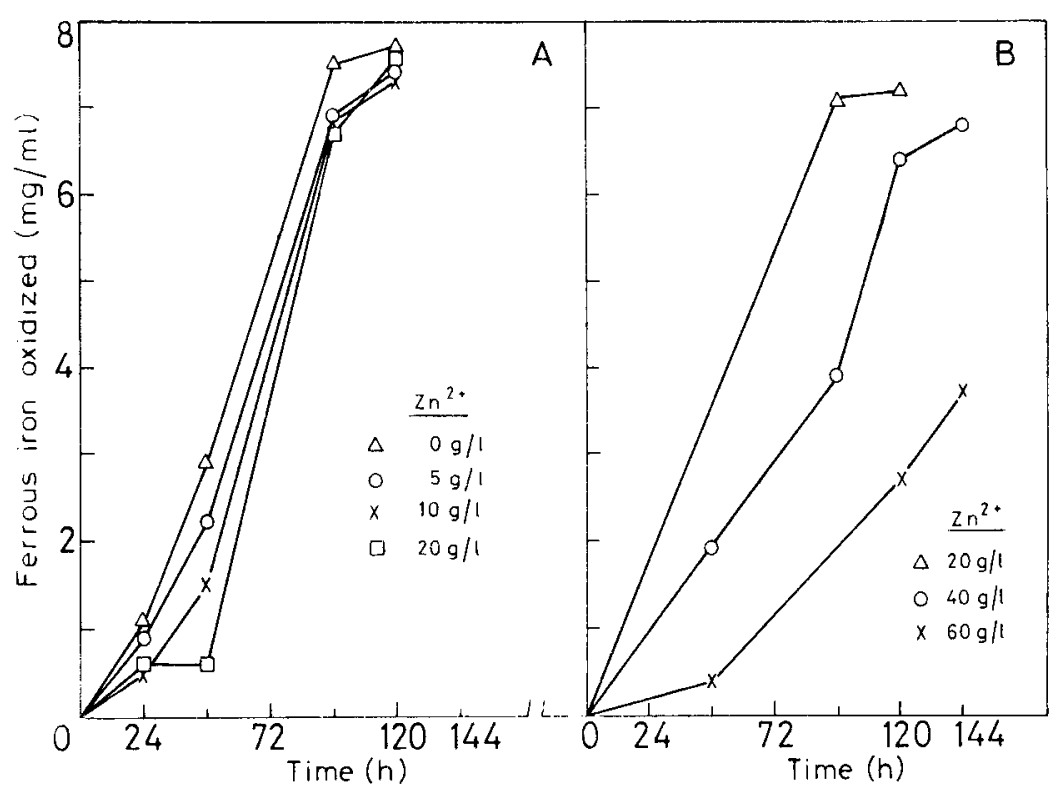

Figure 2. Development of tolerance of $T$. ferrooxidans to increasing levels of $\mathrm{Zn}^{2+}$. Tolerance of $(A)$ unadapted and $(B)$ adapted $(20 \mathrm{~g} / \mathrm{L})$ strains to different concentrations of $\angle \mathrm{n}^{2+}$. 
Table 1. Growth of $T$. ferrooxidans tolerant to $\mathrm{Cu}^{2+}$ and $\mathrm{Zn}^{2+}$, in $9 \mathrm{~K}$ medium containing both metals.

\begin{tabular}{|c|c|c|c|c|c|c|}
\hline \multirow[b]{2}{*}{ Culture } & \multirow{2}{*}{$\begin{array}{l}\text { Cultured in } \\
9 \mathrm{~K} \text { medium } \\
\text { containing }\end{array}$} & \multicolumn{5}{|c|}{ Incubation in days } \\
\hline & & 2 & 6 & 9 & 12 & 25 \\
\hline Zinc tolerant strain $\dagger$ & $\mathrm{Cu}^{2+} 25 \mathrm{~g} / \mathrm{L}$ & $1.6^{\#}$ & 1.9 & $2 \cdot 2$ & $2 \cdot 5$ & $6 \cdot 1$ \\
\hline Copper tolerant strain* & $\mathrm{Zn}^{2+} 40 \mathrm{~g} / \mathrm{L}$ & 1.8 & $3 \cdot 3$ & $6 \cdot 5$ & $8 \cdot 4$ & - \\
\hline Copper tolerant strain & $\mathrm{Cu}^{2+} 25 \mathrm{~g} / \mathrm{L}+\mathrm{Zn}^{2+} 40 \mathrm{~g} / \mathrm{L}$ & $2 \cdot 5$ & $2 \cdot 6$ & $2 \cdot 8$ & $3 \cdot 2$ & 6.8 \\
\hline Zinc tolerant strain & $\mathrm{Cu}^{2+} 25 \mathrm{~g} / \mathrm{L}+\mathrm{Zn}^{2+} 40 \mathrm{~g} / \mathrm{L}$ & $2 \cdot 1$ & $2 \cdot 5$ & $2 \cdot 6$ & $2 \cdot 8$ & 3.5 \\
\hline $\begin{array}{l}\text { Copper tolerant } \\
\text { strain + zinc } \\
\text { tolerant strain }\end{array}$ & $\mathrm{Cu}^{2+} 25 \mathrm{~g} / \mathrm{L}+\mathrm{Zn}^{2+} 40 \mathrm{~g} / \mathrm{L}$ & $2 \cdot 5$ & $2 \cdot 8$ & $2 \cdot 8$ & $3 \cdot 3$ & $6 \cdot 8$ \\
\hline Unadapted strain & $\mathrm{Cu}^{2+} 25 \mathrm{~g} / \mathrm{L}+\mathrm{Zn}^{2+} 40 \mathrm{~g} / \mathrm{L}$ & $0 \cdot 1$ & $2 \cdot 1$ & $2 \cdot 3$ & $2 \cdot 6$ & $3 \cdot 6$ \\
\hline
\end{tabular}

\#Figures are $(\mathrm{mg} / \mathrm{ml}) \mathrm{Fe}^{2+}$ oxidized; $\nmid 40 \mathrm{~g} / \mathrm{L}$ of $\mathrm{Zn}^{2+}$, full growth occurs in $96 \mathrm{~h} ;{ }^{*} 25 \mathrm{~g} / \mathrm{L}$ of $\mathrm{Cu}^{2+}$, full growth occurs in $96 \mathrm{~h}$; ${ }^{(}$Inoculum consisted of $5 \mathrm{ml} \mathrm{Cu}^{2+}$ and $\mathrm{Zn}^{2+}$ tolerant cultures each.

The $\mathrm{Cu}^{2+}$-tolerant strain (row 3 ) can well tolerate the presence of both metals and reaches maximal growth by 25 days. In contrast the $\mathrm{Zn}^{2+}$-tolerant strain (row 4) grew only $50 \%$ as efficient and is comparable with the growth shown by the unadapted strain. The $9 \mathrm{~K}$ medium containing both the metals was inoculated with equal volumes of cultures tolerant to $\mathrm{Cu}^{2+}$ and $\mathrm{Zn}^{2+}$. The growth pattern was similar to the one shown by $\mathrm{Cu}^{2+}$-tolerant strain. The results from the present study reveal that a $\mathrm{Cu}^{2+}$-tolerant strain is better equipped to overcome the inhibition caused by $\mathrm{Zn}^{2+}$. Tuovinen et al (1971) have shown that $T$. ferrooxidans adapted to zinc or nickel are more tolerant to copper compared to unadapted cultures.

The mechanism of metal tolerance is supposed to be due to the ability of the cells to exclude metal ions from their internal structures (Kuznetsov et al 1963). Ingledew and Cobley (1980) and Mjoli and Kulpa (personal communication) have shown that $\mathrm{Fe}^{2+}$ oxidation enzymes are membrane bound in $T$. ferrooxidans. The lag phase that was observed on exposure to metal ions indicates the possibility of an adaptation process taking place for the protection of membrane-bound $\mathrm{Fe}^{2+}$ oxidation enzymes. Also the prolonged lag phase may represent the time when natural selection of metal-tolerant cells takes place (Groudeva et al 1981) while the other susceptible cells in the population succumb to the toxicity of the heavy metals. Thus, development of strains tolerant to $\mathrm{Cu}^{2+}$ and $\mathrm{Zn}^{2+}$ could be the result of adaptation and/or selection of tolerant strains.

\section{Acknowledgement}

The authors thank the DST for financial assistance for this research project through Indo-US-STI.

\section{References}

Groudeva V I, Groudev S N and Markov K I 1981 Comptes rendus de l'Academie bulgare des Sciences 34 375

Ingledew J H and Cobley J G 1980 Biochim. Biophys. Acta 590141

Kunznetsov S I, Ivanov M V and Lyalikova N N 1963 in Introduction to geological microbiology (New York: McGraw Hill Book Co) 
Olson G J and Kelly D P 1986 Biotechnol. Prog. 21

Sakaguchi M, Silver M and Torma A E 1976 Biotechnol. Bioeng. 181091

Silverman M P and Lundgren D G 1959 J. Bacteriol. 77642

Torma A E and Subramanian K N 1974 Int. J. Miner. Process. 115

Torma A E, Walden C C, Duncan D W and Branion R M R 1972 Biotechnol. Bioeng. 14777

Tuovinen O H, Niemela S I and Gyllenberg H G 1971 Antonie van Leeuwenhoek 37489 